\title{
Dr Alexander Voloshanovich: A Critic of the Political Misuse of Psychiatry in the USSR
}

[At the Autumn Quarterly Meeting in 1978, the College passed a Resolution in which it reiterated 'its concern over the abuse of psychiatry for the suppression of the dissent in the Soviet Union' and also expressed its 'admiration and support' for, among others, Dr Alexander Voloshanovich 'whose clinical reports have been invaluable for the brave work in Moscow of the Working Commission to Investigate the Use of Psychiatry for Political Purposes' (Bulletin, January 1979 , p. 6-7).

After receiving official permission, Dr Voloshanovich emigrated from the Soviet Union in February 1980. On 11 March he gave a press conference at the College organized by the Special Committee on the Political Abuse of Psychiatry (Chairman: Dr Peter Sainsbury). Extracts of his statement are printed below. The views expressed there are those of Dr Voloshanovich and do not necessarily represent College policy-Eds.]

'Firstly I want to tell you how I, a rank-and-file Soviet psychiatrist, came to work closely with and share in the lives of the Moscow group investigating the political misuse of psychiatry and became one of their psychiatric consultants. Secondly, I want to tell you about the current assault by the KGB on the Moscow group, and in particular I will describe the recent arrest of my friend Vyacheslav Bakhmin and the growing threat of a similar fate which hangs over his colleagues.

'I was born of Russian parents in 1941 in Kharkov, Ukraine. I left school at the age of 16 , deciding to work and to complete my secondary education at night school. For five years I worked in factories and as a coal miner in the Donbass region, and acquired first-hand knowledge of conditions for workers.

'In 1962 I entered the Kharkov Medical Institute and graduated in 1968. The memory of the invasion of Czechoslovakia in that year and of the hypocrisy of the "invitation" supposedly extended to Soviet troops remains a sickening experience for me to this day. I specialized in psychiatry despite official pressure in favour of general medicine. I joined the All-Union Society of Neurologists and Psychiatrists and started work as a psychiatrist in the Moscow region, remaining there until my resignation in 1979.'

IAs a result of an experience with one case, $\mathrm{Dr}$
Voloshanovich became aware of the possibility that psychiatry was being abused.]

'This led, two years later, in 1977 , to my collaboration with the Working Commission to Investigate the Use of Psychiatry for Political Purposes. My main task was to examine people who had been detained in mental hospitals for political reasons, or had reason to fear that they would be so detained. These people realized that the Commission could defend them more effectively on the basis of a detailed psychiatric report by a qualified psychiatrist like myself, and therefore presented themselves willingly.

'I considered, and still consider, my work to have been medical and humanitarian rather than political in nature but the term "political" has a very wide connotation in the Soviet Union and includes acts such as expressing discontent with local conditions or the actions of superiors, or requesting emigration-even if only to another socialist country.

'I gave my reports to the Working Commission with instructions that copies were to be supplied in confidence only to those psychiatric, legal and human rights groups or individuals who were concerned with the defence of dissenters from psychiatric persecution. Almost all my reports were sent to the Royal College of Psychiatrists.

'After the trial of Commission-member Alexander Podrabinek in August 1978 I gave a press conference for western journalists. I informed them about my reports and told them that in none of the 27 cases I had by then examined had I found any justification for compulsory detention or treatment in mental hospitals, even allowing for possible differences in the criteria for mental illness. I reached the same conclusion in all the $\mathbf{4 0}$ cases I examined.

'After the press conference I expected some official response. It was not long in coming. A medical commission chaired by Professor V. Kovalyov arrived at my hospital. They first tried to persuade me that my conclusions were probably mistaken. They also criticized the voting system at the Honolulu Congress of the World Psychiatric Association (WPA) which had "given Western psychiatrists the chance to make unjustified criticisms of Soviet psychiatry". They asked me for the names of the people I had examined and the mental institutions where they had been held. Believing that their aim was to discredit my work, I only complied with a few of their requests and made my further coopera- 
tion dependent on the inclusion in their commission of an independent WPA observer and on certain other procedural conditions. After this the commission disappeared without trace!

'At this time I was receiving letters and invitations from numerous Western psychiatrists, including Professors Kenneth Rawnsley, Martin Roth, Isaac Marks, and Alec Jenner, and Drs David Watt, Peter Sainsbury and David Clark. I am certain that this support protected me from serious persecution and possible arrest, and I am profoundly grateful to all concerned. Equally, the Working Commission as a whole is deeply appreciative of all the support it has received from abroad over the last three years. This has had an important effect.

'After receiving sudden permission, I emigrated from the USSR on 7 February 1980. It seems that the authorities considered it in their interests to get rid of me.

'Five days later, after my emigration they arrested Vyacheslav Bakhmin, a leading figure in the Working Commission since its formation. This kind, intelligent, scholarly and self-sacrificing man with a lively sense of humour now faces the possibility of charges carrying up to 12 years of imprisonment and exile. Although the exact charges are not yet known, the clear indication is that he will be charged with having circulated-in the Commission's Information Bulletin-material which is either subversive or defamatory of the Soviet political system.

'Such charges will be absurd. The 20 issues of the Bulletin to date, which contain in all some 600 pages of documentation, have been compiled with scrupulous regard for accuracy. Corrections of unintentional errors have been regularly solicited from readers and printed. The probable charges require, as a minimum, the circulation of 'deliberate fabrications' defamatory of the Soviet system. Clearly the bulletins contain very few mistakes, and the few which may have occurred are certainly not deliberate. The Commission has always worked within Soviet law and has regularly sought the help of the relevant official medical and legal bodies.
Within recent weeks the police have also searched the homes of the three other Commission-members and of one of its active supporters.

'Alexander Podrabinek has twice been searched in northeast Siberia, where he is serving a five-year term of exile. This was imposed for his book Punitive Medicine*, which has, incidentally, just appeared in English translation in the USA. Now he is threatened with the initiation of a new case against him and a new sentence.

'For Leonard Ternovsky, a Moscow doctor, his search was a further escalation in the official harassment directed against him since last summer. This has involved, among other things, the disconnecting of his telephone and a threatening interview with his boss, the head of the first Moscow Medical Institute, Professor Petrov.

'The search of Felix Serebrov was followed by his imprisonment for 15 days on a trumped-up charge. As early as 1977 Serebrov received a one-year jail sentence as a result of his work in the Commission. He resumed this work on his release. Now his position is extremely dangerous.

'Finally, Irina Grivnini, an active supporter of the Commission, had two sackfuls of her possessions removed by the searchers. She is a kind and compassionate woman who has done much for inmates of many mental hospitals.

'To conclude, it is important to do everything possible to obtain the release of the victims of Soviet psychiatric abuse-people like the Ukrainian worker and Catholic Iosyp Terelya, the miner and free trades union leader Vladimir Klebanov, the engineer Vladimir Rozhdestvov, the Ukrainian doctor Mykola Plakhotnyuk, the Moscow nun Valeria Makeyeva and the Moscow engineer Nikolai Demyanov.'

* Punitive Medicine by A. Podrabinek, Ann Arbor, Michigan Karoma. 1980. 